\title{
Ecology of gassy, organic-rich sediment in a shallow subtidal area on the Kattegat coast of Denmark
}

\author{
P. R. Dando ${ }^{1}$, T. Fenchel ${ }^{2}$, P. Jensen ${ }^{2}$, S. C. M. O'Hara ${ }^{1}$, S. J. Niven ${ }^{1}$, U. Schuster ${ }^{1, *}$ \\ ${ }^{1}$ Marine Biological Association of the United Kingdom, Citadel Hill, Plymouth PL1 2PB, United Kingdom \\ ${ }^{2}$ Marine Biological Laboratory, University of Copenhagen, Strandpromenaden 5, DK-3000 Helsingør, Denmark
}

\begin{abstract}
Mats of algae are frequently washed inshore along the sandy beaches in the Kattegat after storms and subsequently buried by sand deposition. Sediment cores were taken in May 1991 from one such shallow subtidal area, from which gas bubbles were being released. The organic-rich layer was less than $4 \mathrm{~cm}$ thick; it had extremely high sulphate reduction rates, up to $1.7 \mathrm{mmol}$ sulphate reduced

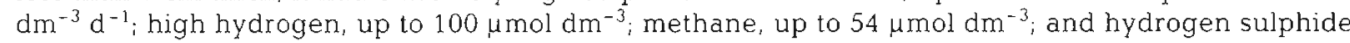
in excess of $1 \mathrm{mM}$. No macrofauna were found in this quicksand area and most of the meiofauna were confined to the uppermost $2 \mathrm{~cm}$. The only metazoan to occur below the $6 \mathrm{~cm}$ zone, and down to a depth of at least $34 \mathrm{~cm}$, was the nematode Sabatieria longispinosa. The anaerobic ciliate Trimyema sp. cf. marinum and the anaerobic flagellate Hexamita sp. dominated the highly reducing, organic-rich zone at 2 to $6 \mathrm{~cm}$ depth; they also occurred below this zone together with a few specimens of Euplotes sp.
\end{abstract}

\section{INTRODUCTION}

Anaerobic decomposition of organic matter in sandy sediment leads to the formation of a zone with high concentrations of reducing compounds such as hydrogen sulphide, methane and ammonia. The lack of oxygen and the presence of hydrogen sulphide result in the occurrence of a specialised infaunal community (Fenchel 1969, Fenchel \& Riedl 1970). On many beaches the major organic input is of mats of macroalgae blown inshore after being dislodged by storms. Some of these mats degrade near the highwater mark whilst others are buried by sand forming an organic-rich zone in the sediment. The rates of breakdown and the ecology of macroalgal mats washed up between the tidemarks have been the subject of several studies (Koop et al. 1982, McLachlan 1985, McGwynne et al. 1988) but there is little information on the ecology of algal mats buried below the low-water mark.

\footnotetext{
- Present address: Department of Biology, University of Essex, Colchester CO4 3SQ, United Kingdom
}

During the study of a methane seep area (Dando et al. 1993a, b) in May 1991 on a sandy beach at Bangsbostrand, south of Frederikshavn on the Kattegat coast of Denmark, we found an area of yielding sand (quicksand) in the shallows from which gas bubbles were released when pressure was applied to the surface. Along this beach methane seeps to the surface in places from the deep reservoirs below this part of the Kattegat (Jensen et al. 1992, Dando et al. 1993a). We initially believed that the quicksand was due to the saturation of the sand with methane seeping from these underlying reservoirs; however, examination of sediment cores from the quicksand showed that the gas originated in a layer of decomposing algae buried a few $\mathrm{cm}$ below the sediment surface. This paper describes the chemical and biological characteristics of this organic-rich ephemeral zone which is common to many beaches.

\section{METHODS}

Sediment sampling and chemistry followed previously described methods (Dando et al. 1991). For 
chemistry and faunal analysis, all the sediment cores from the quicksand patch were taken within $1 \mathrm{~m}$ of each other towards the centre of the approximately $1000 \mathrm{~m}^{2}$ area on 7 May 1991. The core positions are shown in Fig. 1. Control cores were collected north of the area of natural gas seepage at a similar distance from the beach. Samples for chemistry and microbial rate measurements and for meiofauna were collected in translucent PVC tubes of $55 \mathrm{~mm}$ i.d. The cores were extruded and sampled in $20 \mathrm{~mm}$ sections to a depth of $34 \mathrm{~cm}$ for methane, hydrogen, ammonia, sulphate, elemental sulphur, dissolved sulphide, thiosulphate, sulphite, acid-labile sulphide, chromous reducible sulphide, organic and inorganic carbon, nitrogen, $\mathrm{pH}$ and Eh. Sulphate reduction and methane oxidation rates were measured in subsamples taken from these cores, and $10 \mathrm{ml}$ subsamples were taken for meiofauna counts. Interstitial water was extracted and analysed, sulphur species determined and sulphate reduction rates measured on $4 \mathrm{ml}$ subcores taken from each section. The sulphate reduction tubes were incubated at the temperature of the sediment for $19 \mathrm{~h}$ and the end products of reduction, $\mathrm{S}^{0}, \mathrm{FeS}$ and $\mathrm{FeS}_{2}$, were reduced to $\mathrm{H}_{2} \mathrm{~S}$ and trapped in zinc acetate. Dissolved sulphide, sulphite and thiosulphate were reacted with monobromobimane under argon and the derivatives separated and determined by high-performance liquid chromatography (HPLC; Newton et al. 1981). Sediment carbon and nitrogen contents were measured using a CHN analyser (Verardo et al. 1990). Methane and hydrogen were separated by gas chromatography on a $2.15 \mathrm{~m}$ column of $13 \mathrm{X}$ molecular sieve, using zero-grade nitrogen as carrier. The gases were detected using a Figaro TGS 711 solid-state detector.

Samples for protozoa were collected by pressing $30 \mathrm{~cm}$ long plastic cylinders, i.d. $45 \mathrm{~mm}$, into the sediment. The core tubes had a vertical row of $1 \mathrm{~mm}$ diameter holes $1 \mathrm{~cm}$ apart. These holes were filled with silicone rubber. On removing a tube from the sediment it was stoppered at both ends and taken to the laboratory where 1 or $2 \mathrm{ml}$ samples of interstitial water were removed by piercing the silicone plugs with a hypodermic needle. The ciliates were counted by removal with a capillary pipette and identified under a dissection microscope.

Sediment subsamples from the cores collected for sediment chemistry analysis were examined directly under a dissecting microscope at $25 \times$ magnification for 'soft meiofauna organisms', i.e. gastotrichs, gnathostomulids and turbellarians. Other samples were fixed in $4 \%$ formalin and stored for later examination for 'hard meiofauna organisms', i.e. harpacticoid copepods, kinorhynchs, nematodes, oligochaetes and ostracods These samples were treated as in Jensen (1983).

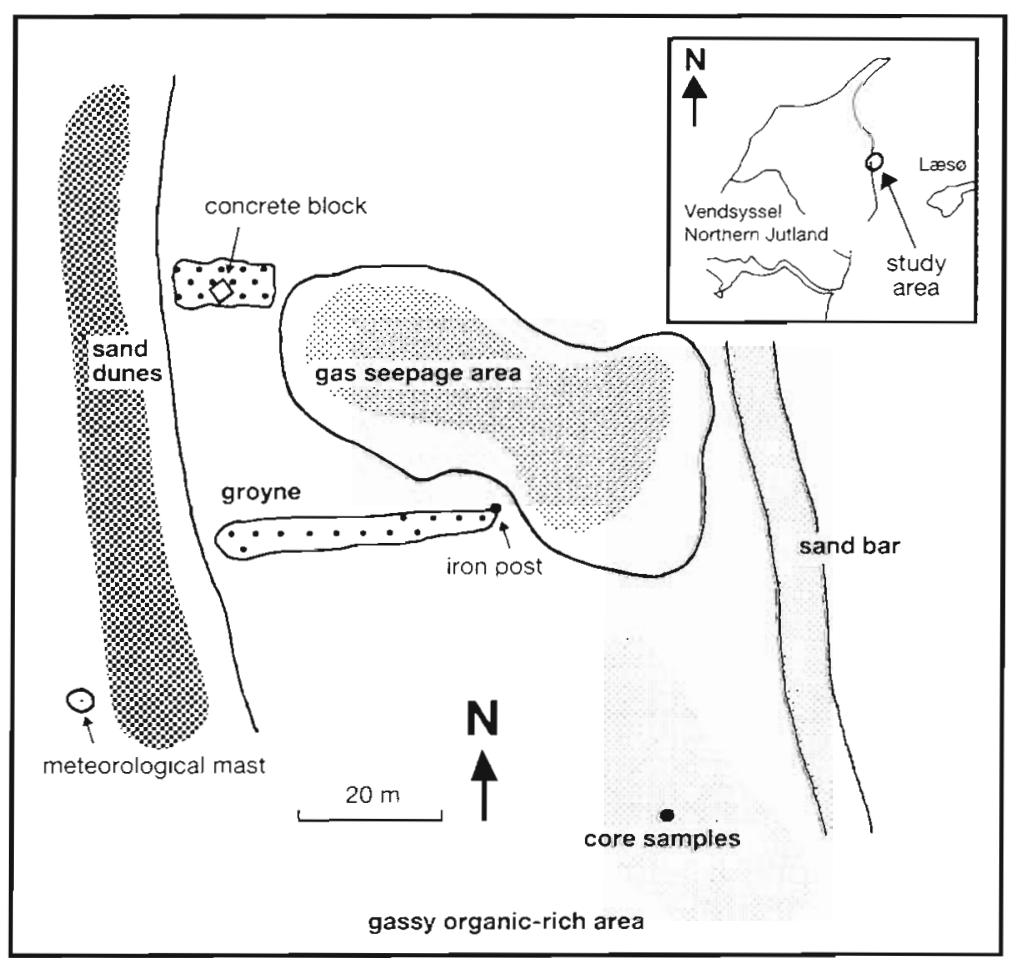

Fig. 1 Map (inset) and plan of site showing the position of the gassy, organic-rich sediment observed in May 1991 and the location of the sediment cores examined

\section{RESULTS}

\section{Site description}

The area studied at Bangsbostrand lies $5 \mathrm{~km}$ south of Frederikshavn on the shores of the Kattegat (Fig. 1). On the landward side a line of sand dunes separates the sandy beach from arable fields. Seawards the beach is stabilised by 35 to $40 \mathrm{~m}$ long groynes constructed of boulders. The groynes were built at intervals of approximately $80 \mathrm{~m}$ along the beach. The area of quicksand studied was in a subtidal area which was separated from the sea by an exposed sand wave during extreme low water (Fig. 1). It was $75 \mathrm{~m}$ from the edge of the area of carbonatecemented sandstone deposits where methane seeps occurred. At the time of sampling, the sediment temperature was $8.1^{\circ} \mathrm{C}$ and the overlying water was approximately $20 \mathrm{~cm}$ deep under low water conditions. More detailed descriptions of the water and sand movements and of the fauna in the intertidal and the 
shallow subtidal area off this beach are given elsewhere (Dando et al. 1993a, b).

Similar quicksand areas were found at the same water depths elsewhere along the beach. When these areas of sand were stepped on, or core tubes were pushed into them, gas bubbles broke the surface. The gas had an offensive odour which was probably due to a combination of butyric acid, hydrogen sulphide and organic sulphur compounds. These areas of gas-charged sediment were free of gas by the following October and were not present on this beach the following May. Such quicksand areas are not uncommon on this part of the Kattegat coast of Vendsyssel and on the beaches of the island of Læsø in areas where mats of Laminaria spp., up to $15 \mathrm{~cm}$ or more thick, are washed ashore after storms and often buried by subsequent sand deposition.

\section{Sediment chemistry}

The parallel cores A.1 \& A2 from the gassy sediment both showed an organic-rich layer with an increased porosity at 2 to $6 \mathrm{~cm}$ depth (Fig. 2). A second minor organic enrichment occurred at 14 to $16 \mathrm{~cm}$, as shown by slight increases in organic carbon and nitrogen and water content. The 2 to 4 and 4 to $6 \mathrm{~cm}$ horizons were of a fine black sand, below this the sand shaded to grey and was coarser with shells. Inorganic carbon reached a minimum of $0.02 \%$ of dry weight in the 4 to $6 \mathrm{~cm}$ horizon, increasing to $>0.75 \%$ of dry weight below this. Both cores showed very similar depth profiles for hydrogen, methane, ammonia, sulphur species and sulphate reduction rates (Figs. 3 to 6). Our initial impression, that the gas in the sediment was methane escaping from the interglacial and early Weischelian deposits (Dando et al. 1993a), was not supported by the methane profiles in the sediment (Fig. 3) or by analysis of the gas. Collected gas samples contained a maximum of $30 \%$ methane, in contrast to $>99 \%$ methane in gas samples from the methane seeps $75 \mathrm{~m}$ to the north (Fig. 1).

The sharp fall in $\mathrm{pH}$ and Eh (Fig. 7) in the 2 to $6 \mathrm{~cm}$ horizon and the peak in sulphate reduction rates (Fig. 6) indicated active fermentation of the organic
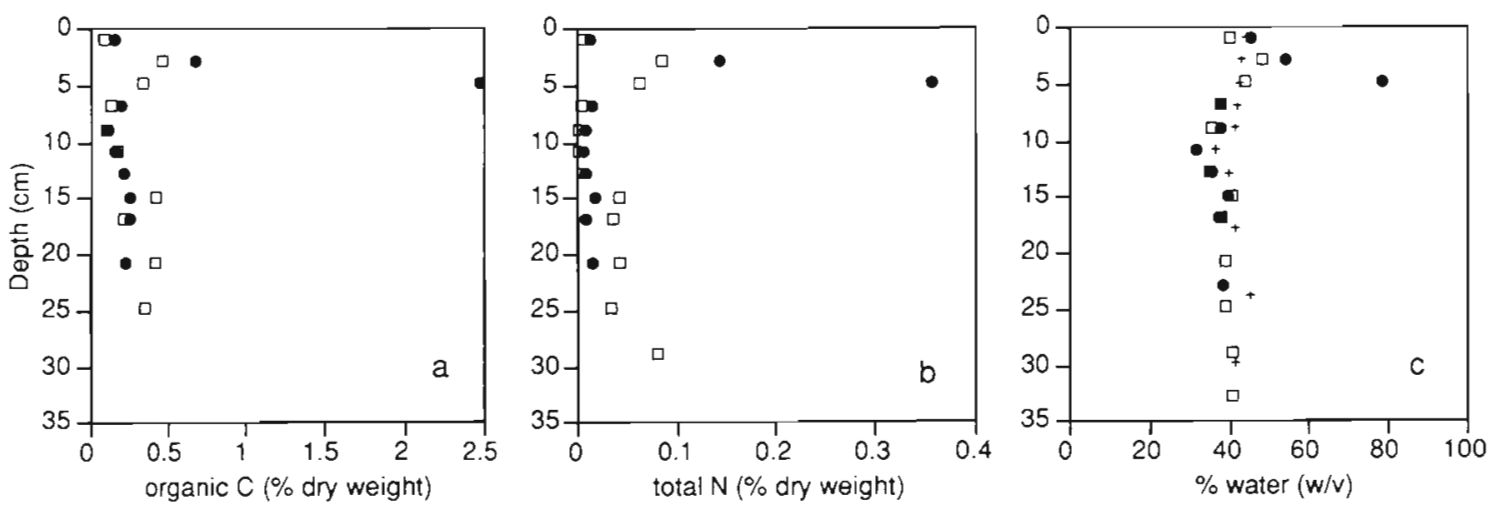

Fig. 2. Depth profiles of (a) organic carbon, (b) nitrogen and (c) water content in cores A1 (•) and A2 ( $\square$ ) taken from the position shown in the gassy sediment in Fig. $1_{i}(+)$ data from control cores collected north of the natural gas seep
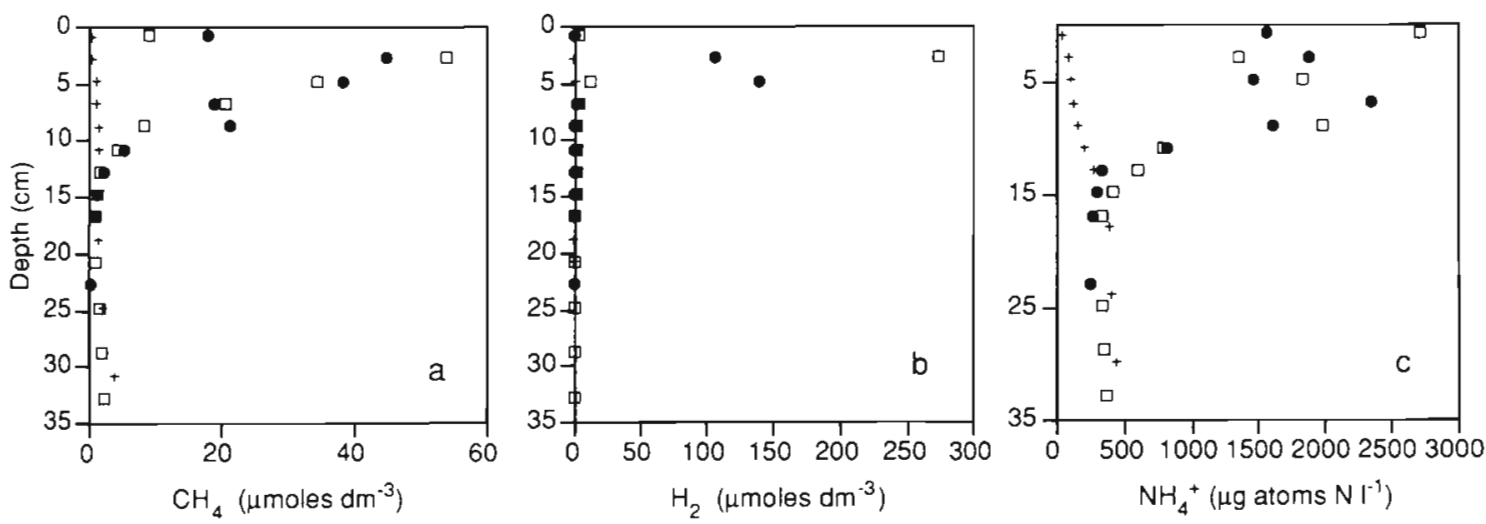

Fig. 3. Concentrations of (a) methane, (b) hydrogen and (c) ammonia in the sediment cores; symbols as for Fig. 2 

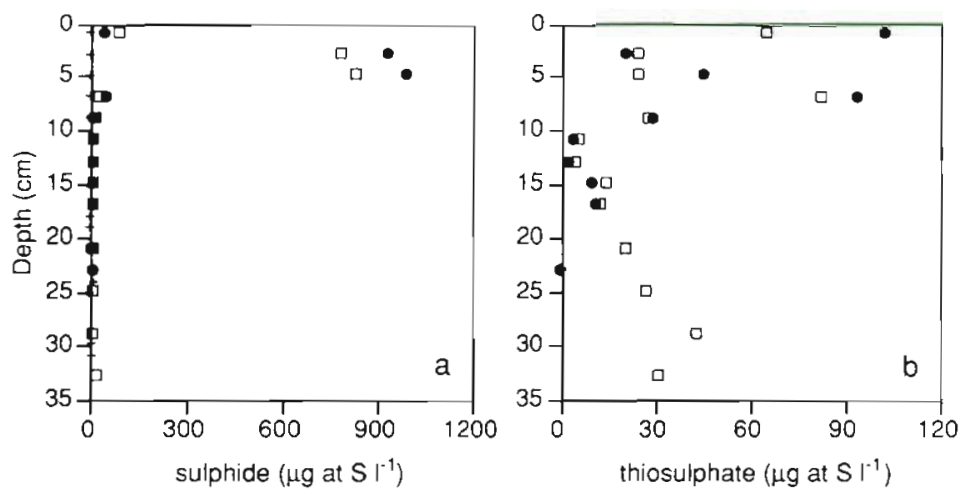

pronounced minimum at 3 to $5 \mathrm{~cm}$ depth coinciding with the zone of intense sulphate reduction (Fig. 6a), again contrasting markedly with the typical progressive depletion of sulphate with depth seen in cores from elsewhere on the beach. The sulphate reduction rates are minimum estimates since up to $80 \%$ of the ${ }^{35} \mathrm{~S}$ added was reduced during the $19 \mathrm{~h}$ incubation period. Sulphate depletion would have limited the reduction rate in the sealed subcores. There was a minor second peak of sulphate reduction at 12 to $16 \mathrm{~cm}$ depth,
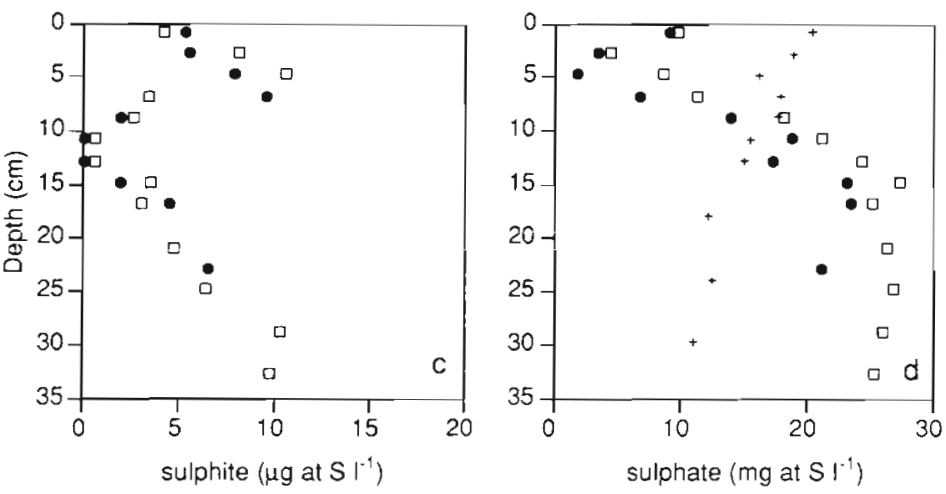

Fig. 4. Profiles of (a) sulphide, (b) thiosulphate, (c) sulphite and (d) sulphate in the interstitial water; symbols as for Fig. 2

matter, Methane, hydrogen and hydrogen sulphide all peaked in this zone, showing very different profiles from the control cores (Figs. $3 \& 4$ ). The concentration profile for methane indicated that it diffused both upwards and downwards from the 2 to $6 \mathrm{~cm}$ layer. Much of the sulphide was precipitated as iron sulphide in the organic-rich layer and oxidised to thiosulphate and elemental sulphur both above and below this zone (Figs. 4 \& 5). Hydrogen was also rapidly consumed away from the thin layer of active fermentation.

The sulphate profiles (Fig. 4d) were unusual with a coinciding with a minor peak of organic matter in the sediment. This second maximum was also demonstrated by a slight increase in acid-labile sulphide in this region in both cores (Fig. 5b).

Bolh ammonia (Fig. 3) and thiosulphate (Fig. 4) were highest in the 0 to 2 and 6 to $8 \mathrm{~cm}$ horizons, just outside the region of active fermentation. Neither thiosulphate nor sulphite were detected $(<0.1 \mu \mathrm{M})$ in the cores from the control site. Elemental sulphur was high in the upper $2 \mathrm{~cm}$ of the gassy sediment cores, peaked again at 4 to $6 \mathrm{~cm}$ and then tended to decrease with depth, falling sharply in concentration below $18 \mathrm{~cm}$ (Fig. 5).

The high hydrogen concentrations, up to $276 \mu \mathrm{mol}$ $\mathrm{dm}^{-3}$ sediment, were in sharp contrast to the concen-

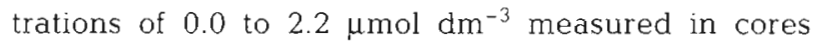
collected from elsewhere on the beach in May. Similarly, the methane concentrations in the upper $10 \mathrm{~cm}$ of 3 cores taken away from the methane seepage and organic-rich areas on the beach were in the range 0.5

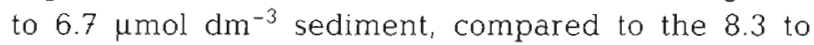
$54.1 \mu \mathrm{mol} \mathrm{dm}{ }^{-3}$ found in the upper $10 \mathrm{~cm}$ of sediment in the quicksand area. The $\mathrm{pH}$ of interstitial water from other sites on the beach did not fall below 7.40, in con-
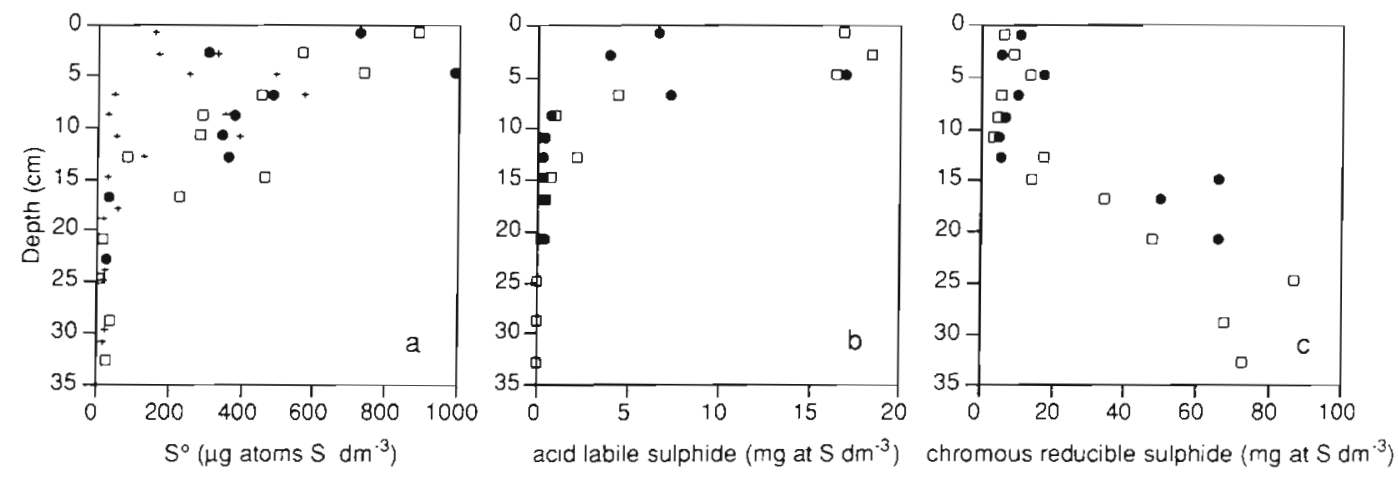

Fig. 5. Profiles of (a) elemental sulphur, (b) acid-labile sulphide and (c) chromous reducible sulphide in the cores; symbols as for Fig. 2 


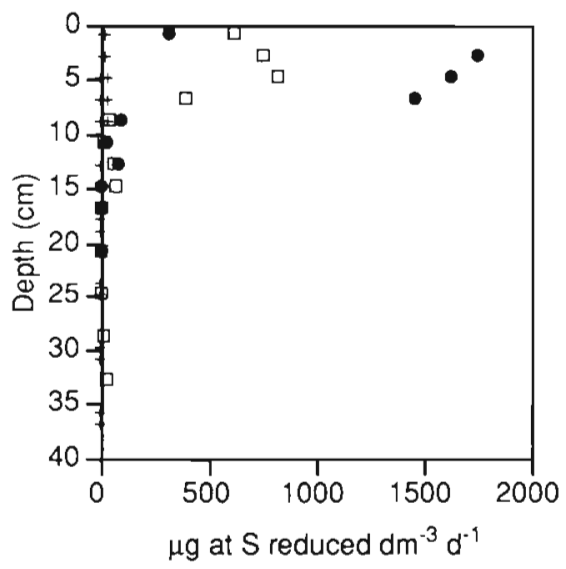

Fig. 6. Profiles of sulphate reduction rates in the cores; symbols as for Fig. 2

trast to the minimum of 6.91 recorded here, again emphasising the active fermentation. Sulphate concentrations reached a minimum of $1.9 \mathrm{mM}$ in the interstitial water from the organic-rich layer compared to minima in excess of $15 \mathrm{mM}$ in the upper $10 \mathrm{~cm}$ of sediment from elsewhere on the beach at Bangsbostrand

\section{Protozoa}

There were at least 12 species of ciliates present in the upper $2 \mathrm{~cm}$ of sediment. This reduced to 2 , of which 1 species, Euplotes sp., was represented by a single individual in the organic-rich zone at 2 to $6 \mathrm{~cm}$ depth. The obligate anaerobic ciliate Trimyema sp. cf. marinum dominated in this zone and was also the major species below this depth (Table 1). The Trimyema sp. resembles T. marinum (Karl) but differs with respect to the number of kineties and other details (Augustin et al. 1987). The organic-rich zone also harboured large (uncounted) numbers of the anaerobic flagellate Hexamita sp. upper layers of the sediment elsewhere in this region (Dando et al. 1993b). Nematodes were the only metazoan inhabitants of the organic-rich zone, 2 to $6 \mathrm{~cm}$ depth, and the few individuals found, 1 to 2 per $10 \mathrm{ml}$, were species present in the upper $2 \mathrm{~cm}$ layer which may have been dragged into the lower layer during core collection. Below this zone there were only 2 species and densities were equally low. The nematode Sabatieria longispinosa inhabited the sediment column below this zone from 6 to $34 \mathrm{~cm}$, the deepest layer examined.

\section{DISCUSSION}

In both chemistry cores from the quicksand area the molar concentration of hydrogen was 2- to 3-fold greater than that of methane. The maximum concentration of hydrogen observed was $273 \mu \mathrm{mol} \mathrm{dm} \mathrm{dm}^{-3}$ sediment. High hydrogen concentrations are produced as a by-product of carbohydrate and protein digestion by anaerobic bacteria under high organic loading (Wohlin 1982). Under these conditions the low $\mathrm{pH}$, due to rapid acid production (Foree \& McCarty 1970), inhibits the activity of hydrogen-utilising methanogens. The $\mathrm{pH}$ minimum in the cores corresponded to the hydrogen maximum. Due to the coarse $(2 \mathrm{~cm})$ sections taken, relative to the sharp gradients, it is probable that the hydrogen concentrations were higher and the $\mathrm{pH}$ lower in the most active layer. However, the minimum $\mathrm{pH}$ actually measured was close to the known optima for some methanogens growing on hydrogen and carbon dioxide (Zehnder \& Wuhrmann 1977). There was an unmeasured volume of free gas in the upper sediment layers. We were therefore unable to calculate the dissolved concentrations of hydrogen and methane present, since these, unlike hydrogen sulphide, were measured in total sediment and not in extracted inter-

\section{Metazoa}

No macrobenthic species were found. The meiofauna was largely concentrated in the upper $2 \mathrm{~cm}$ of the sediment. Harpacticoid copepods were present in low numbers, 2 to 4 individuals per $10 \mathrm{ml}$, only in this zone in both cores. There were 15 nematode species in the upper $2 \mathrm{~cm}$ layer with an abundance of 72 individuals per $10 \mathrm{ml}$. The dominant species were Daptonema normandicum and Sigmophoranema rufum. Both species are diatom feeders and are confined to the
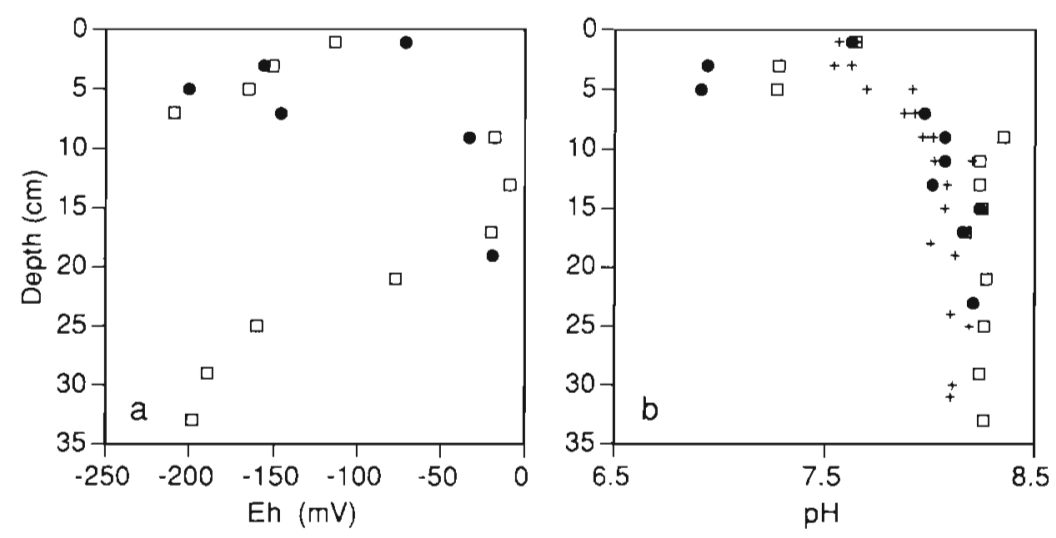

Fig. 7. Profiles of (a) redox potential (Eh) and (b) $\mathrm{pH}$ in the sediment cores; symbols as for Fig. 2 
Table 1. Number of protozoa $\mathrm{ml}^{-1}$ sediment

\begin{tabular}{|c|c|c|c|c|c|c|c|c|}
\hline \multirow[t]{2}{*}{ Species } & \multicolumn{7}{|c|}{ Sediment depth $(\mathrm{cm})$} & \multirow[b]{2}{*}{$10-12$} \\
\hline & $0-1$ & $1-2$ & $2-3$ & $3-4$ & $5-6$ & $6-8$ & $8-10$ & \\
\hline Pleuronema sp. & 6 & 7 & - & - & - & - & - & - \\
\hline Cristigera sp. & 6 & - & 17 & - & - & - & - & - \\
\hline Unidentified spp. & 11 & 5 & - & - & - & - & - & - \\
\hline Aspidisca sp. & 2 & & & - & - & - & - & - \\
\hline Trachelodyla sp. & - & - & 2 & - & - & & - & - \\
\hline Remanilla margaritifera & - & 2 & - & - & - & - & - & - \\
\hline Unidentified sp. A & - & 23 & 10 & - & - & _- & - & - \\
\hline Tracheloaphis spp. & - & 1 & 1 & - & - & - & - & - \\
\hline Loxophyllum sp. & - & 1 & - & & - & - & - & - \\
\hline Chaenia sp. & - & - & 2 & - & - & - & - & - \\
\hline Lacrymaria sp. & - & - & 2 & - & - & - & - & - \\
\hline Euplotes sp. & - & - & 1 & - & - & 1 & - & 3 \\
\hline Trimyema sp. cf. marinum & - & - & 15 & 330 & 24 & 37 & 132 & 7 \\
\hline Total & 25 & 39 & 50 & 330 & 24 & 38 & 132 & 9 \\
\hline
\end{tabular}

stitial water. The dissolved concentration of hydrogen in the interstitial water is therefore unknown.

The sulphate reduction maximum also corresponded with the hydrogen maximum; hydrogen-utilising sulphate-reducing bacteria are as common as those utilising acetate in Kattegat sediments (Jorgensen \& Bak 1991). The reduction in thiosulphate in this zone is also likely to be due to consumption by sulphate reducers. With the greatly enhanced sulphate reduction rates in the 4 to $6 \mathrm{~cm}$ zone, the depth-integrated values were 102 and $54 \mathrm{mmol}$ sulphate reduced $\mathrm{m}^{-3}$ sediment $\mathrm{d}^{-1}$ for Cores A1 \& A2 respectively. These rates are higher than for sediment cores elsewhere on this beach, including the methane seepage zone, which were in the range 1.1 to $17.1 \mathrm{mmol}$ sulphate reduced $\mathrm{m}^{-3}$ sediment $d^{-1}$ (Dando et al. 1993b).

In both cores an ammonia minimum coincided with the hydrogen maximum. This may represent ammonia consumption by sulphate-reducing and methanogenic bacteria. No equivalent minimum was observed in cores from the control site.

The major oxidation product of sulphide, in both oxic and anoxic sediments, is thiosulphate (Jørgensen \& Bak 1991). As with thiosulphate the other oxidation products of sulphides, sulphite and elemental sulphur, accumulated particularly in the upper $2 \mathrm{~cm}$ of sediment. Sulphite reached a minimum concentration in the 10 to 14 cm horizon, corresponding with the Eh maximum zone in the sediment core. We do not know the major route of sulphite production in sediment. It is possible that it is one of the products of anoxic oxidation of sulphides as well as a product of sulphate reduction. The sulphite profile does not mimic that of sulphide or of sulphate reduction. Sulphite was not detectable in the interstitial water taken from the control cores.

Macrofauna and meiofauna are known to be reduced in areas of buried seaweed, or in the littoral zone subject to leachates of algal mats, due to toxicity by hydrogen sulphide and other reducing compounds (McLachlan 1985, McGwynne et al. 1988). The present organic-rich layer, however, forms a very suitable habitat for the obligate anaerobic ciliate Trimyema sp. cf. marinum. A similar protozoan biota, almost entirely Trimyema spp. and Hexamita spp., has been observed in anaerobic batch cultures containing large amounts of fermenting organic material with the accumulation of volatile fatty acids (T. Fenchel unpubl.). Trimyema species have hydrogenosomes (organelles with a hydrogenase) and the marine species do not harbour methanogenic endosymbionts. These ciliates are therefore assumed to generate hydrogen. Based on the size and numbers of this ciliate in our samples they could not have generated more than $300 \mathrm{nmol} \mathrm{H}_{2} \mathrm{dm}^{-3}$ sediment $\mathrm{h}^{-1}$ (see Fenchel \& Finlay 1992). Below the highly reducing fermentive zone the metazoa were almost exclusively represented by the nematode Sabatieria longispinosa, a species known to penetrate deep in anaerobic sandy bottom layers (Jensen 1987).

This study shows only one time frame in the environmental changes during the anaerobic degradation of a buried algal mat. This habitat under the sand is equivalent to that in an anaerobic digestor or a cow rumen (Pavlostathis \& Giraldo-Gomez 1991). Since the first-order decay constant for anaerobic decomposition of the biodegradable fraction of algae is of the order of 0.01 to $0.03 \mathrm{~d}^{-1}$ (Foree \& McCarty 1970) and stranded kelp mats can decompose in 8 d (Koop et al. 1982), such habitats are ephemeral, although recurring several times a year in the Kattegat. They leave a sand enriched in iron sulphides which can be utilised as an energy source by bivalves with symbiotic sulphuroxidising bacteria such as Lucinoma borealis (Dando et 
al. 1986), whose shells frequently litter the beach at Bangsbostrand.

Acknowledgements. We acknowledge the use of the facilities at the Havbiologisk Feltlaboratorium, University of Copenhagen, Frederikshavn and thank Lesley Taylor for assistance with analysis and with the figures. This study was supported by the CEC, MAST programme contract no. 0044, and by the Carlsberg Foundation.

\section{LITERATURE CITED}

Augustin, H., Foissner, W., Adam, H. (1987). Revision of the genera Acineria, Trimyema and Trochiliopsis (Protozoa, Ciliophora). Bull. Br. Mus. nat. Hist. (D: Zool.) Ser. 52: $197-224$

Dando, P. R., Austen, M. C., Burke, R. J., Kendall, M. A., Kennicutt, M. C., Judd, A. G., Moore, D. C., O'Hara, S. C. M., Schmaljohann, R., Southward, A. J. (1991). Ecology of a North Sea pockmark with an active methane seep. Mar. Ecol. Prog. Ser, 70: 49-63

Dando, P. R., O'Hara, S. C. M., Jensen, P., Schuster, U., Taylor, L. J., Clayton, C. J., Baylis, S., Laier, T. (1993a). Gas seepage from a carbonate-cemented sandstone reef on the Kattegat coast of Denmark. Mar. Pet. Geol. (in press)

Dando, P. R., O'Hara, S. C. M., Niven, S. J., Schmaljohann, R., Schuster, U., Taylor, L. J. (1993b). The effects of methane seepage at an intertidal/shallow subtidal site on the shore of the Kattegat, Vendsyssel, Denmark. Bull. geol. Soc. Den. (in press)

Dando, P. R., Southward, A. J., Southward, E. C. (1986). Chemoautotrophic symbionts in the gills of the bivalve mollusc Lucinoma borealis and the sediment chemistry of its habitat. Proc. R. Soc. (B) 227: 227-247

Fenchel, T (1969). The ecology of marine meiobenthos. IV Ophelia 6: 1-182

Fenchel, T., Finlay, B. J. (1992). Production of hydrogen and methane by anaerobic ciliates containing symbiotic methanogens. Archiv. Microbiol. 157: 475-480

Fenchel, T., Riedl, R. J. (1970). The sulfide system: a new biotic community underneath the oxidized layer of marine sand bottoms. Mar. Biol. 7: 255-268

This article was presented by A. J. Southward, Plymouth, UK
Foree, E. G., McCarty, P. L. (1970). Anaerobic decomposition of algae. Environ. Sci. Technol. 4: 842-949

Jensen, P. (1983). Meiofaunal abundance and vertical zonation in a sublittoral soft bottom, with a test of the Haps corer. Mar. Biol. 74: 319-326

Jensen, P. (1987). Differences in microhabitat, abundance, biomass and body size between oxybiotic and thiotrophic free-living marine nematodes. Oecologia 71.564-567

Jensen, P., Aagaard, I., Burke, R. A., Dando, P. R., Jorgensen, N. O., Kuijpers, A., Laier, T., O'Hara, S. C. M., Schmaljohann, R. (1992). 'Bubbling reefs' in the Kattegat: carbonate-cemented rocks support a diverse ecosystem at methane seeps. Mar. Ecol. Prog. Ser. 83: 103-112

Jorgensen, B. B., Bak, F. (1991). Pathways of thiosulfate transformations and sulphate reduction in a marine sediment (Kattegat, Denmark). Appl. environ. Microbiol. 57: $847-856$

Koop, K., Newell, R., Lucas, M. I. (1982). Biodegradation and carbon flow based on kelp (Ecklonia maxima) debris in sandy beach microcosm. Mar. Ecol. Prog. Ser. 7; $315-326$

McGwynne, L. E., McLachlan, A., Furstenberg, J. P. (1988). Wrack breakdown on sandy beaches - its impact on interstitial meiofauna. Mar. environ. Res. 25: 213-232

McLachlan, A. (1985). The biomass of macro- and interstitial fauna on clear and wrack-covered beaches in western Australia. Estuar. coast. Shelf Sci. 21:587-599

Newton, G. L., Dorian, R., Fahey, R. C. (1981). Analysis of biological thiols: derivatization with monobromobimane and separation by reverse-phase high performance liquid chromatography. Analyt. Biochem. 114:383-387

Pavlostathis, S. G., Giraldo-Gomez, E. (1991). Kinetics of anaerobic treatment. Wat. Sci. Tech. 24: 35-59

Verardo, D. J., Froelich, P. N., McIntyre, A. (1990). Determination of organic carbon and nitrogen in marine sediments using the Carlo Erba NA-1500 analyzer. Deep Sea Res. 37: 157-165

Wohlin, M. J. (1982). Hydrogen transfer in microbial communities. In: Bull, A. T., Slater, J. H. (eds.) Microbial interactions in communities, Vol. 1. Academic Press, Inc., London, p. 323-356

Zehnder, A. J. B., Wuhrmann, K. (1977). Physiology of a Methanobacterium strain AZ. Arch. Microbiol. 111: 199-205

Manuscript first received: April 7, 1993

Revised version accepted: July 7, 1993 